Bojana Filipović, master pedagog ${ }^{1}$, OŠ „Radovan Kovačević- Maksim“, Lebane Tijana Đokić, master pedagog ${ }^{2}$ OŠ „Sestre Radović“, Belosavci
UDC: $37.018 .1 / .2: 159.923 .38$

doi: $10.19090 /$ ps.2019.2.155-167

Primljen: 20. 2. 2019.

Prihvaćen: 18. 11.2019.

STRUČNI NAUČNI RAD

\title{
UTICAJ PORODICE I ŠKOLE NA RAZVOJ KREATIVNOSTI KOD DECE
}

\author{
Apstrakt
}

U savremenom društvu se naglašava značaj kreativnosti ali se i ukazuje na potrebu za dodatnim podsticanjem i razvijanjem kreativnosti. Razvijanjem i podsticanjem kreativnosti, stvaralaštva, radoznalosti dece i razvijanjem njihovog mišljenja, zapravo se radi na kreiranju čvrste osnove za dalji razvoj kreativnosti, odnosno kreativnog pojedinca, budućeg odraslog člana društva. Napredak i uspešnost svake društvene zajednice neposredno su uslovljeni njenim odnosom prema stvaraocima i stvaralaštvu, koje treba kao najdragoceniji potencijal čuvati, negovati i razvijati. Kako su učitelji, odnosno nastavnici ti koji sa decom provode veliki deo dana i koji pored roditelja, $u$ velikoj meri utiču na dete i njegov celokupan razvoj, potrebno je razmotriti i koji je njihov udeo u razvoju kreativnosti dece školskog uzrasta. Bitno je stvoriti povoljnu klimu, ne samo u okviru obrazovno-vaspitne ustanove, već i u samoj porodici kako bi se stvorili povoljni uslovi za maksimalno razvijanje kreativnih potencijala kod svakog deteta, odnosno svakog pojedinca. Ovim radom smo nastojali da teorijski sagledamo i istaknemo značaj koji porodica i škola, odnosno roditelji i nastavnici imaju za razvoj kreativnosti kod dece osnovnoškolskog uzrasta.

Ključne reči: kreativnost, divergentno mišljenje, porodica, vaspitni stil, škola

\section{Uvod}

Iako je prva asocijacija na kreativnost umetnost i umetničko stvaralaštvo, kreativnost se ne sme ograničiti samo na ovaj aspekt ljudskog delovanja. Čini se da nakon predškolskog perioda, upisom u prvi razred osnovne škole, dolazi do smanjivanja broja dece koja problemima, odnosno njihovim rešenjima, pristupaju na kreativan način. Porodica je ta koja nas oblikuje, u njoj stičemo prva iskustva i ostvarujemo prve kon-

\footnotetext{
${ }^{1}$ bojanafilipovic91@gmail.com

22djokictijana614@gmail.com
} 
takte sa svetom. Najpre roditelji, a kasnije i šira porodica, su ti preko kojih spoznajemo šta se dešava u svetu oko nas; roditelji su nam prvi izvor informacija, oni su ti koji mogu podsticati ili suzbijati kreativnost svoje dece. Kada govorimo o ovome, svakako treba imati na umu da nisu sve porodice iste, da nisu svi roditelji isti, odnosno da nisu vaspitni stilovi roditelja isti. Ne odnose se svi roditelji na jednake načine prema svojoj deci, nemaju iste stavove o tome kako treba vaspitati i odgajati dete, koje su bitne osobine koje treba razvijati kod deteta, na koji način treba stimulisati detetovu radoznalost i sklonost ka maštanju. Upravo zbog toga, kada govorimo o podsticanju kreativnosti kod dece, a naročito dece školskog uzrasta, govorimo o saradnji i međusobnom uticaju koji na dete ostvaruje kako porodica, odnosno roditelji, tako i škola. U ovom radu ćemo se baviti kreativnošću dece, sagledanom kroz uticaje porodice i škole na podsticanja kreativnosti dece.

\section{Definisanje pojma kreativnost}

Kreativnost je proces i osobina koja obuhvata sve aspekte života, zalazeći i ispoljavajući se kroz različite sadržaje i aktivnosti. Tako shvaćena, kreativnost zaista predstavlja kompleksan i slojevit pojam i proces. Maksić (2006: 36) skreće pažnju na činjenicu da se „najčešće govori o kreativnom pojedincu, odnosno o kreativnoj ličnosti, te se ona definiše kao pojedinac kome jedinstveni sklop ličnosti omogućava da u određenim okolnostima stvara nove proizvode koji imaju širi društveni značaj". U skladu sa tim navodimo i definiciju koju daju Krulj i Arsić (2008) u okviru koje se kreativnost određuje kao sposobnost za koju se smatra da je sastavljena od širokog kvantuma osobina koje svi članovi određene populacije poseduju na određenim stupnjevima razvoja, a kao faktori se navode asocijativna fluentnost i fluentnost ideja, originalnost, adaptivna i spontana fleksibilnost i sposobnost logičkog vrednovanja.

Prilikom definisanja kreativnosti, možemo navesti i određene osobine koje su karakteristične za ličnost koju smatramo kreativnom. Osobine koje se ispoljavaju prilikom procesa kreativnosti su:

1. ,fluentnost, koja predstavlja sposobnost stvaranja hipoteza i ideja;

2. fleksibilnost, koja se ogleda u elastičnosti mišljenja, odnosno brzom prelaženju sa jedne ideje na drugu. Odsustvo ove osobine nazivamo inertnost mišljenja ili funkcionalna fiksiranost;

3. originalnost predstavlja sposobnost pojedinca da uoči nešto što drugi nisu uočili, da pronađe neuobičajene odgovore, odnosno da dođe do onih rešenja koja se razlikuju od standardnih i opšteprihvaćenih;

4. neukalupljenost, odnosno otvorenost za nova iskustva i ideje, odnosno uzdržavanje od prihvatanja i davanja standardnih odgovora;

5. pronicljivost, koja se manifestuje u sposobnosti odvajanja onoga što je u jednom problemu specifično od nespecifičnog, uspostavljanju novih veza i analogija, sintezi ideja u novu celinu; 
6. divergentno mišljenje, koje se odnosi na sposobnost pojedinca da problemu priđe sa više aspekata, traganje za novim rešenjem, koje odstupa od onog najlakšeg, već poznatog rešenja (Kamenov, 2006: 296).

\section{Divergentno mišljenje}

Pod divergentnim mišljenjem podrazumeva se traganje za novim, drugačijim načinima definisanja, razumevanja i interpretiranja problema. U skladu sa tim, možemo reći da kreativnost odgovara upravo tipu otvorenog, odnosno divergentnog mišljenja. Divergentno mišljenje je generativno, informacija se vrednuje u odnosu na njenu mogućnost da stimulira, pokrene ideju, ali i istraživačko i nepredvidivo jer se u većoj meri zasniva na intuiciji, dok se logički sled radnji i operacija zanemaruje (Bognar, 2010). Divergentno mišljenje se odvija u široko određenim okvirima, sa slobodnim normama i raznovrsnim mogućnostima odgovora. Kao takvo divergentno mišljnje usmereno je na traganje i davanje izvrsnih, neprosečnih, odgovora, omogućava da do izražaja dođe mašta, jedinstvenost i originalnost pojedinca (Supek i saradnici, 1987).

Iako smo istakli da divergentno mišljenje vodi do originalnih ideja i mnogobrojnih rešenja problema, ipak divergentno mišljenje nije jednako kreativnosti, te ističemo da se divergentno mišljenje ne sme poistovećivati i sinonimno koristiti sa kreativnošću, jer kreativnost predstavlja širi pojam od divergentnog mišljenja.

\section{Uticaj porodice na razvoj kreativnosti kod dece}

Porodica vrši funkcije primarne grupe, omogućujući neposredni kontakt, ličnu povezanost, razvijanje emocija, podstiče da se razvije ljubav kao potreba, te možemo da kažemo da je porodica organizacija koja podstiče razvitak i emocionalne strane ličnosti, stvarajući time i uravnoteženu ličnost (Kamenov, 2006). U društvene činioce, od kojih zavisi razvoj darovitosti i kreativnosti, spadaju porodica (porodični odnosi, socijalno stanje i kulturna klima), škola (organizacija i oblici rada, motivacija i kreativnost nastavnika), lokalna zajednica (vanškolske aktivnosti mladih, društvena i kulturna klima) i društveni sistem (propisi kojima se uređuje obrazovanje darovitih, sistem stimulacija i vrednovanja kreativnosti i stvaralaštva ljudi).

S tim u vezi, Ivanović (2008) govori o socijalnim uslovima, odnosno o materijalno- kulturnim uslovima i socijalnoj podršci, ističući da oni ne samo da omogućavaju detetu da iskaže kreativne sklonosti, već i da se na osnovu njih razvije organizovana aktivnost i dugoročno usmeravanje mladih u negovanju darovitosti. U odnosima sa roditeljima, dete stiče sigurnost, razvijajući i osećaj pripadnosti zajednici. Briga, ljubav i nežnost koju dete dobija od svojih roditelja pružaju mu osećaj poverenja- u sebe i druge. Takođe, nigde kao u porodici, nisu tako velike mogućnosti da se pripada zajednici, a da se ne izgubi individualnost ličnosti (Maleš, 1993). U najširem spektru zahteva koji 
se odnose na osnovne pretpostavke i uslove za uspešan razvoj darovitosti i kreativnosti u porodici, naročito se ističu sledeći:

1. pozitivni međuporodični odnosi (međusobna ljubav, razumevanje i poštovanje);

2. pozitivni ljudski kvaliteti roditelja i njihov autoritet (odnos roditelja prema društvenoj stvarnosti, prema drugim ljudima, prema radu);

3. obavezni minimum opšte i pedagoške kulture roditelja i pravilno shvatanje uloge vaspitača i zadataka vaspitanja i obrazovanja od strane roditelja (roditelji kao vaspitači moraju imati osnovna i najnužnija znanja o cilju i zadacima vaspitanja i obrazovanja, kao i o uslovima, putevima i sredstvima pomoću kojih se oni ostvaruju, a takođe veoma je važno da shvate da su pred društvenom zajednicom odgovorni za vaspitanje svoje dece i da im je dužnost vaspitača jedna od najvažnijih i najodgovornijih);

4. poznavanje psihofizičkog razvitka deteta i njegovih potreba i mogućnosti (roditelji moraju poznavati osnovne zakonomernosti psihofizičkog razvoja deteta, jer samo tako mogu doprineti optimalnom razvoju svoga deteta i izbeći nelagodnosti koje se mogu javiti precenjivanjem ili podcenjivanjem sposobnosti deteta, što je posebno značajno onda kada se darovitost i kreativnost nađu u disproporciji između nerealnih želja roditelja i stvarnih mogućnosti dece);

5. povoljni materijalni i zdravstveno-higijenski uslovi (porodica treba da poseduje adekvatan stambeni prostor u kome će dete imati svoj kutak za rad i odmor, da postoje uslovi za održavanje lične higijene i stambenog prostora);

6. povoljni uslovi za kulturni život porodice (kulturni nivo roditelja, mogućnost korišćenja sredstava za podizanje opšte kulture u porodici -štampa, knjige, radio i televizija, pristup internetu, mogućnost odlaska u bioskop, pozorište, na koncert, utakmicu, izložbu) (Krulj i Arsić, 2008).

\section{Vaspitni stilovi roditelja i razvoj kreativnosti kod dece}

Govoreći o uticaju koji porodica, odnosno roditelji u najvećoj meri, imaju na razvoj ličnosti deteta i njegove kreativnosti, svakako je potrebno baviti se i vaspitnim stilovima roditelja i načinom na koji se njihov uticaj manifestuje.

Istraživanjem koje su realizovali Kornel i Grozberg (Cornell \& Grossberg, 1987) skrenuta je pažnja na značaj i ulogu porodičnih uslova za razvoj skladne i stabilne ličnosti darovite dece, pri čemu se kao najvažnije karakteristike porodične sredine za uspešno lično prilagođavanje darovite dece izdvajaju koheziju, otvorenost i spremnost za učešće u konfliktima. Kohezija predstavlja stepen posvećenosti, pomoći i podrške koju članovi porodice pružaju jedni drugima. Otvorenost je mera u kojoj su članovi porodice ohrabreni da deluju otvoreno i direktno izražavaju svoja osećanja, dok se konflikti izražavaju preko količine otvorenog pokazivanja ljutnje, agresije i sukoba među članovima porodice. Rezultati ispitivanja ukazuju da je za detetovo 
prilagođavanje najvažniji kvalitet porodične interakcije koja treba da bude otvorena i kooperativna, sa izbegavanjem sukoba i slobodom za lično izražavanje. Vaspitni stil roditelja možemo definisati kao relativno dosledne načine ponašanja roditelja kojima se uspostavljaju odnosi sa decom (Matejević, 2007). Govoreći o vaspitnom stilu roditelja, potrebno je ukazati na činjenicu da roditeljski par, odnosno osobe koje ga sačinjavaju, ne moraju imati isti pristup vaspitanju, te samim tim neće imati iste vaspitne stilove. Matejević (2007) razlikuje tri vaspitna stila, i to:

1. autoritarni, u okviru koga možemo razlikovati toplo- ograničavajući i hladno-ograničavajući vaspitni stil;

2. demokratski, koji možemo smatrati toplo usmeravajućim i

3. liberalni, u okviru koga razlikujemo toplo- popustiljiv i hladno- popustljiv vaspitni stil.

Deca koja potiču iz porodica u kojima se primenjuje demokratski stil vaspitanja znatno su kooperativnija i prijateljski raspoloženija od dece vaspitavane u strožim uslovima (Stojanović, 2008). Demokratski stil utiče na razvoj samostalnosti, kreativnosti i drugih pozitivnih crta ličnosti dece, odnosno učenika i doprinosi njihovom boljem funkcionisanju u školi i, šire posmatrano, u društvenom životu. Kamenov (2006) smatra da su deca koja su demokratski vaspitavana aktivna i socijalno ekstrovertna, kao i da se kod njih zapaža originalnost, radoznalost, konstruktivnost, jer ih način kontrole zapravo oslobađa, dozvoljavajući im da istražuju i eksperimentišu, te kao takva zauzimaju povoljan status u grupi.

Sa druge strane, imamo roditelje koji u vaspitanju dece primenjuju autoritarni i liberalni vaspitni stil. Deca koja dolaze iz ovakvih, autoritarnih porodica, su mirna i povučena. Kod njih je konformizam razvijen i to na visokom nivou, a samim tim je smanjena radoznalost, originalnost, maštovitost, kreativnot. Deca čiji su roditelji okarakterisani kao autoritarni se najbolje prilagođavaju (Kamenov, 2006). Što se liberalnog vaspitnog stila tiče, bez obzira o kojoj dimenziji da govorimo, kao glavna karakteristika se izdvaja davanje slobode detetu. Roditelji toplo- popustljivog liberalnog vaspitnog stila detetu ne postavljaju ograničenja, smatrajući da se time dete i njegov razvoj sputava i da će ga postavljanjem granica samo frustrirati. Ukoliko odrasta u ovakvoj sredini, dete će biti kreativno, uz razvijen pozitivan odnos prema svetu, neće podnositi autoritarne grupe i institucije. Međutim, kod ove dece se ne razvija osećaj odgovornosti, budući da su roditelji ti koji im ispunjavaju sve želje. Sa druge strane, hladno- popustljive roditelje karakteriše nebriga za dete, njegove želje i potrebe. Ovakav odnos prema detetu dovodi do toga da deca postaju agresivna (Matejević, 2007). Na osnovu ovoga vidimo da razvoju kreativnosti kod dece najviše doprinosi demokratski vaspitni stil, ali i da se kreativnost može razviti i kod dece čiji roditelji primenjuju liberalni vaspitni stil.

Istraživanjem koje je bilo usmereno na strategije koje roditelji primenjuju (Tsai, 2000) utvrđeno je da uspešne roditeljske strategije obuhvataju: provođenje vremena sa 
decom tako da ona od toga imaju koristi; razumevanje dece slušanjem i razgovorom; podučavanje dece od najranijeg detinjstva obezbeđivanjem stimulativnog okruženja; ohrabrivanje dece da rade dobro pružanjem modela za ugledanje; jačanje dečijih dobrih navika; saopštavanje očekivanja deci kroz diskusiju sa njima; gledanje televizije i dobrih programa sa decom; pružanje izazova deci postavljanjem ciljeva zasnovanih na njihovim sposobnostima; izgrađivanje detetovog samopoverenja; koordinisanje konzistentnog truda između roditelja i nastavnika; ohrabrivanje dece da postanu kreativna i produktivna; pomaganje deci da naprave ravnotežu u onome čemu se posvećuju. Roditelji koji su učestvovali u ispitivanju ističu značaj izgrađivanja navika od ranog detinjstva i izjavljuju da su njihova uspešna deca razvila dobre navike učenja. Učenje je deo dnevne rutine, a pored navike učenja razvijane su i druge navike, kao što su pravilno uzimanje hrane, vežbanje, lepo ponašanje, poštovanje muzike i likovnih umetnosti, nerasipanje novca.

Potkrepljivanje ohrabrivanjem i iskustvo uspeha učinili su da deca postanu ponosna na sebe, da se osećaju udobno sa sobom, da postave sopstvene ciljeve i da budu visoko motivisana da postignu te ciljeve. Ispitivani roditelji imali su svest o potrebi i uspešnosti koordinisanog konzistentnog truda u radu na dečijem razvoju sa njihovim nastavnicima. Oni su isticali da je važno da otac i majka komuniciraju međusobno i da imaju usklađene stavove prema obrazovanju, kao i da se dogovaraju oko najboljih strategija roditeljstva. Takođe, i očevima i majkama je bilo jasno da treba da daju potrebne informacije nastavnicima svoje dece, da ih podržavaju i da rade zajedno sa njima na podsticanju dečijih talenata $i$ kreativnosti. U kontaktima sa školom, roditelji su pomogali nastavnicima da naprave adekvatnije, više individualizovane programe za učenike koji su bili od veće koristi u pružanju podrške njihovim sposobnostima.

Smatra se da roditelji mogu biti pouzdani u identifikaciji kreativnosti dece, za razliku od škole i nastavnika koji mogu biti nesvesni u pogledu dečjih neakademskih mogućnosti i sposobnosti. Svakako da informacije koje roditelji mogu da daju nastavnicima mogu biti korisne da se promeni slika o detetu, koje može biti procenjeno kao "neobično" ili "neobuzdano". Takođe, roditelji mogu postati uspešniji u procenjivanju i identifikaciji kreativnosti, pa i darovitosti, svoje dece, ali je potrebna saradnja sa školom i nastavnicima zarad dobijanja specifičnih informacija i kriterijuma za procenjivanje i identifikaciju (Đorđević, 2008). Podrška maštovitosti i kreativnosti u detinjstvu (kako u predškolskom periodu, tako i u osnovnoj školi) može biti posmatrana ne samo kao poželjan preduslov za razvoj kreativne orijentacije pojedinca i izražavanja kreativnog ponašanja u odraslom dobu, već i kao pokretačka sila daljeg društvenog razvoja (Pavlović i Maksić, 2009). Na osnovu ovoga zaključujemo da razvijanje i podsticanje kreativnosti kod dece, nema značaj samo za dete, buduću odraslu osobu, već i za društvo u celini. 


\section{Obrazovanje i kreativnost- uticaj i međusobna povezanost}

Govoreći o odnosu škole i kreativnosti, autorke Đorđević i Maksić (2005) zaključuju da je današnja škola takva da učenicima kazuje da se najpre treba učiti, a posle će se planirati i živeti; da postoji jedan tačan odgovor, tako da nema rizika i susreta sa nepoznatim; nastavnici ne poznaju učenikove kapacitete jer posmatraju samo njegovu kompetentnost u određenom predmetu; deca uče da su nesposobna, da ne znaju i da čak ne mogu ni da nauče. Mladi treba da razviju uverenje da su sposobni, da treba da pokušavaju sve dok ne uspeju, da budu odgovorni za to što rade. Kreativna škola mora biti zasnovana na poverenju u učenika, a što se potvrđuje mogućnostima adekvatnog komuniciranja, poštovanja svakog učesnika u komunikaciji, zanimljivim kurikulumom i raznovrsnošću obrazovnih sadržaja (koja podrazumeva diferencijaciju).

Muminović (2009) smatra da je kreativnost u nastavi nešto specifičnija i složenija u odnosu na druge oblasti delovanja, zbog toga što uključuje više faktora koji sukcesivno ili simultano deluju i determinišu je. Pored nastavnog sadržaja koji se proučava, razvoj i postojanje kreativnosti na času, odnosno u nastavi, determinišu kako nastavnik, tako i učenik, odnosno učenici. Međutim, kreativna utemeljenost nastave se ne završava ni sa ova tri faktora, već je determiniše i pozitivna povezanost, odnosno korelacija ova tri faktora, ali i mnogih drugih koji su u njenoj osnovi. Na nivou učionice kreativnost se može podsticati kroz nastavne i vannastavne aktivnosti i kroz razvoj podsticajne školske klime. Na nivou obrazovnog sistema podsticanje kreativnosti iziskuje promene u okviru nastavnog programa, profesionalnog razvoja nastavnika, razvijanje sistema za upravljanje kreativnošću. Na nivou društva potrebno je veće vrednovanje kreativnosti (Pavlović i Maksić, 2009). Svaki pojedinac ima i može da razvije svoj lični talenat. Lične sposobnosti razvijaju se kroz individualni trud i uz pomoć intervencija iz okruženja. Podrška koja će olakšati razvoj ličnog talenta posebno je važna u slučaju pojedinaca koji žele postignuće visokog nivoa i to u više oblasti. Razvoj individualnog talenta ili svih talenata pojedinca jednako je važan kao i podsticanje razvoja jednog specifičnog talenta (Đorđević i Maksić, 2005).

Decu moramo učiti da postanu kreativne osobe, koje su u stanju da inoviraju i improvizuju. Ne smeju se bojati promena, nego se moraju osećati prijatno u promenama i inovacijama. Oni moraju biti ljudi koji se neće suprotstavljati promenama, nego treba da ih anticipiraju. Svako učenje koje predstavlja jednostavnu aplikaciju prošlosti na sadašnjost ili korišćenje tehnika u sadašnjoj situaciji postaje besmisleno u mnogim područjima života. Nama treba nova vrsta ljudskih bića koji su u stanju odvojiti se od prošlosti (Bognar, 2010).

\section{Uloga nastavnika u podsticanju kreativnosti kod učenika}

Kreativnost ne možemo razvijati u školi koja kod dece ne podstiče i ne razvija osetljivost za probleme, ne pružajući učenicima priliku da otkriju ono što je izvan- 
redno i neobično, ne dozvoljavajući mu da razvije elastičnost mišljenja jer se susreće sa problemima za koje najčešće postoji (se nudi i uvažava) samo jedno tačno rešenje (Supek i saradnici, 1987).

Da bi se kreativnost negovala i razvijala u obrazovnom sistemu današnjice, neophodno je omogućiti učenicima da dožive kreativni proces u kome mogućnosti postanu stvarnost. Popesku (Popescu, 2013) navodi da je poželjno kreativnost podsticati kroz sopstveni model ponašanja vaspitača, učitelja, nastavnika ili profesora; stvarati aktivnosti koje uključuju znanja iz različitih oblasti kako bi se razvio interdisciplinaran način razmišljanja; negovati atmosferu u kojoj su greške neophodan deo procesa učenja a ne negativna pojava; naučiti decu da preuzmu odgovornost kako za svoje uspehe tako i za svoje neuspehe; podsticati decu i pomoći im da gledaju na stvari iz tuđih i različitih uglova, uz razvijanje saosećanja i emotivne inteligencije. Uz navedeno, neophodno je podsticati kreativnu saradnju, ali i dati deci dovoljno vremena da razmisle na kreativan način.

Kada govorimo o školi, svakako da u najširem smislu mislimo na učitelje i nastavnike, i jačinu uticaja koji imaju na učenike i njihov razvoj, budući da su svakodnevno sa učenicima. U tom smislu, odgovornost nastavnika i učitelja je velika, te opravdano možemo reći da je uloga učitelja nezamenljiva, pre svega, u prepoznavanju područja kroz koje će se talenat iskazati, kao i u prenošenju osnovnih znanja na učenike, razvijanju motivacije kod njih, ali i u izgrađivanju mnogobrojnih karakteristika ličnosti (Balažević, 2010). Rad sa decom koji se odvija na fleksibilan i kreativni način implicira da je detetu data mogućnost izbora, kao i mogućnost da iskaže svoje individualne karateristike (Đorđević, 2008). Kako je prirodna radoznalost deteta u odnosu na svet koji ga okružuje, jedan od glavnih pokreatača aktivnosti i procesa učenja, govoreći o podsticanju kreativnosti u školi, zapravo govorimo i o podsticanju radoznalosti dece. Brojnim eksperimentima sprovedenim tokom šezdesetih i sedamdesetih godina dvadesetog veka, dokazano je da se u nastavi može podsticati kreativnost, pri čemu je neophodno poštovati principe: uvažavati neobična pitanja, uvažavati neobične i maštovite odgovore i ideje, pokazati učenicima da njihove ideje imaju vrednost, spojiti evaluaciju sa uzrocima i posledicama, obezbediti i vreme u kome nema ocenjivanja (Bognar, 2010).

Istražujući obrazovno-vaspitnu praksu i način na koji se kreativnost razvija u sadašnjem obrazovno-vaspitnom sistemu, Maksić (2006) ističe da nastavnike koji su uspešni u radu na razvijanju talenata i kreativnosti svojih učenika odlikuje sposobnost da organizuje nastavu koja je primerena mogućnostima učenika. Uspešni su oni nastavnici koji dozvoljavaju veće mogućnosti izbora svojim učenicima pri određivanju tema koje će obrađivati; nastavnici koji zastupaju neortodoksna stanovišta; nastavnici koji nagrađuju divergentno mišljenje; nastavnici koji rade sa uživanjem svoj posao; nastavnici koji neformalno komuniciraju sa učenicima izvan učionice. Uspešni nastavnici hrabre učenike da dovedu u sumnju pretpostavke od kojih polaze nastavni sadržaji; dozvoljavaju greške u radu učenika; podstiču učenike da preuzimaju umereni rizik; 
daju kreativne naloge i procene učenicima. U cilju podsticanja kreativnosti učenika, nastavnici moraju da im pruže priliku da sami definišu probleme koje će proučavati; nagrađuju ideje i produkte do kojih učenici dođu u procesu saznavanja; obezbeđuju dovoljno vremena za ispoljavanje kreativnog mišljenja u nastavi; podstiču učenike da tolerišu nejasnoće. S tim u vezi, Li (Lee, 2013) predlaže nekoliko saveta za podsticanje kreativnosti, navodeći da je odvajanje od konvencija je jedan od glavnih faktora kreativnosti. Kako bi razvijali kreativnost kod svojih učenika, nastavnici i učitelji, treba da poseduju razvijenu toleranciju i da podstiču učenike da učestvuju u aktivnostima koje zahtevaju istraživanje, testiranje, traženje i veštine pretpostavljanja. Trebalo bi razviti avanturistički duh u nastavi, razviti naviku da se obradi pun potencijal različitih ideja, podsticati decu da rade i eksperimentišu sa oblicima i idejama, kao i da budu svesni svog okruženja. Davanje učenicima mogućnost izbora podstiče njihovo aktivno učešće u aktivnostima i nastavi, što je neophodno za dalje kreativno učešće učenika.

$\mathrm{Na}$ osnovu svega navedenog, možemo zaključiti da je projektna nastava jedan od načina rada kojima se može podsticati kreativnost učenika, budući da uključuje rešavanje problema, kritičko razmišljanje, kolaborativno i samostalno učenje, kao i stavljanje zadatka u širi kontekst.

\section{Tehnike za razvoj kreativnog mišljenja}

Kreativnost može razviti samo ona škola u kojoj se neguje mišljenje, rasuđivanje, istraživanje, dijalog, razmenjivanje ideja. Zbog toga, neophodno je da se klasične učionice zamene novim, savremenijim takozvanim radionicama znanja i kreativnosti. Kreativnost može i mora biti zastupljena i prisutna u svakoj etapi izvođenja nastave, odnosno u celokupnom nastavnom radu (Muminović, 2009). Najbolji način podsticanja kreativnosti je onaj koji se reflektira kroz stvaralačku igru karakterističnu za razdoblje detinjstva (Somolanji i Bognar, 2008). Ukoliko se samostalne, odnosno slobodne aktivnosti dece u školi organizuju kako treba, mogu da predstavljaju priliku za kreativno, slobodno i stvaralačko izražavanje dece, pri čemu bi deca razvijala i svoje sposobnosti i mogućnosti. U takvim aktivnostima deca bi trebala da imaju priliku da nesputano ispoljavaju svoju inicijativu, pri čemu bi učitelji i nastavnici bili u ulozi pomoćnika i partnera, a ne rukovodioca (Kamenov, 2006).

Kako bi se omogućilo oslobađanje kreativnih potencijala, koji bi se dalje razvijali, neophodno je ispuniti dva uslova: obezbediti psihološku sigurnost, koja je spoljašnja, pod kojom podrazumevamo osećanje da je dete prihvaćeno i psihološku slobodu, koja za razliku od sigurnosti, potiče iz samog deteta, zasniva se na igranju simbolima, pronalaženju novih načina upotrebe (Bognar, 2010). Neke od tehnika koje ovaj autor predlaže jesu:

1. slučajni pojmovi je jedna od najjednostavnijih tehnika za razvoj kreativnosti i divergentnog mišljenja. Slučajni pojmovi mogu biti reči ili sličice. Slučajne reči možemo dobiti na nekoliko načina, jedan od njih je zapisivanje reči na 
posebnim karticama. Zatim se izvlači kartica na kojoj je napisana određena reč i razmišlja o njenim svojstvima i onome na šta ona asocira. Gotovo svaka izabrana reč će podstaći nova rešenja i ideje o temi, odnosno o postavljenom problemu;

2. postavljanje pitanja, pri čemu postoji šest univerzalnih pitanja koja nam omogućavaju dolaženje do novog rešenja: Šta? Gde? Kada? Kako? Zašto? Ko?;

3. šest šešira je tehnika koju je osmislio De Bono, a pored toga što se koristi za podsticanje kreativnog mišljenja, može se koristiti i u druge svrhe. Suština ove tehnike je u tome da se, nakon postavljanja problema, za svaku situaciju stvore alternative koje proizilaze iz očiglednih rešenja. U okviru ove tehnike imamo podelu mišljenja na šest različitih načina, koji su metaforički prikazani šeširima.

Pored toga, bitno je koristiti oblike nastave koji omogućuju veću samostalnost učenika: skupni oblik nastave, rad u paru i samostalno, omogućiti deci slobodu izbora problema, kad god je moguće, ukloniti vremensko ograničenje iz aktivnosti razvoja kreativnog mišljenja, negovati razmenjivanja ideja dece i učitelja i dece međusobno, koristiti portfolije koje svaki učenik popunjava samostalno odabranim i evaluiranim radovima- umesto klasičnog ocenjivanja, korišćenje savremene tehnologije (Bognar, 2004). Za kreativno rešenje problema takođe bitno da nastavnik, uz pokazano interesovanje, prizna i eventualno, vlastito neznanje, te da podstakne učenike na traženje odgovora.

\section{Zaključak}

Ovim radom smo samo nastojali da ukažemo, pre svega, na značaj kreativnosti za kako pojedinca, tako i samo društvo, ali i da skrenemo pažnju i na značaj porodice i škole, kao dva najvažnija i najznačajnija faktora i činioca razvoja svakog deteta. Iako se, možda čini da porodica i škola na ovom polju nemaju dodirnih tačaka i da se u tom smislu i njihovi uticaji na pojedinca (u ovom slučaju uticaj na dete, učenika) mogu posmatrati odvojeno, ipak je potrebno shvatiti da se uticaji i delovanja ova dva činioca društvenog razvoja međusobno prepliću. Ne možemo izdvojiti jedan od ova dva faktora tvrdeći da jedan od njih u većoj meri utiče na razvoj kreativnosti deteta.

Navedeni faktori i njihova delovanja na pojedinca međusobno se ne isključuju i ne potiru, već zajedničkim snagama vrše uticaj na dete, podstičući ili suzbijajući kreativnost. Kao što smo istakli, mnogobrojni autori smatraju da je današnje društvo društvo kome su kreativni pojedinci potrebni, ali da se, sa druge strane, škole, odnosno čitavi sistemi ne organizuju tako da podstiču kreativnost i kreativni pristup problemima, već da čine upravo suprotno. Sa druge strane, zbog loše materijalno-ekonomske situacije roditelji imaju sve manje vremena da se bave svojom decom, da aktivno i pozitivno utiču na njihov razvoj, te dolazi do toga da roditelji ne realizuju aktivnosti sa decom koje bi dovele do podsticanja i razvijanja kreativnosti. Kreativnost se, kao što 
smo i istakli, ne mora razvijati samo i isključivo putem umetničkih sadržaja, već i kroz nastavne sadržaje u okviru drugih predmeta. Pored toga, treba raditi na obrazovanju roditelja i podizanju svesti o značaju kreativnosti, ali i o tome kojim se aktivnostima može pozitivno uticati na dete, u cilju razvijanja njegove kreativnosti. Porodica i škola, odnosno roditelji i nastavnici,su ti koji svojim delovanjem ostavljaju trajne posledice na dete i način na koje ono vidi svet, a samim tim i način na koji organizuje i provodi svoje vreme. Porodica i škola svojim delima oblikuju budućnost, jer njihovi sadašnji i trenutni uticaji utiču na buduće ponašanje pojedinca, njegov odnos prema sebi, drugima i svetu.

\title{
Bojana Filipović, Tijana Đokić
}

\section{THE INFLUENCE OF FAMILY AND SCHOOL ON THE DEVELOPMENT OF CHILDREN'S CREATIVITY}

\begin{abstract}
The importance of creativity has been emphasized in modern society, but the need for its additional encouragement and improvement has been pointed out as well. By developing and stimulating children's creativity, curiosity and thinking, a solid foundation is set up for its further advancement, i.e. creative individual, a future adult member of our society. The progress and success of each social community is directly conditioned by its relationship towards creators and creativity, which should be preserved, nurtured and developed as the most valuable potential. As teachers are those who spend most of the time with children and who, in addition to their parents, greatly influence them and their overall development, it is necessary to consider their role in the development of creativity of school-age children. It is important to create favorable climate, not only in the educational institution, but also in family itself, in order to impose conditions for the utmost development of creative potential in each child, i.e. each individual. This paper is a theoretical review and highlights the importance of family and school, parents and teachers, for the development of creativity in primary school children.
\end{abstract}

Keywords: creativity, divergent thinking, family, parenting style, school

\section{Literatura}

Balažević, E. (2010): Kreativnostunastavi- Učiteljiiorganizacijakreativnihaktovnostiunastaviglazbenekulture, Životi škola. 56(23), 181-184. 
Bognar, B. (2004): Poticanje kreativnosti u školskim uvjetima, Napredak. 145(3), 269284.

Bognar, B. (2010): Škola koja razvija kreativnost, 1-17. Dostupno na: https://www. google.rs/url? sa $=$ t\& $r c t=j \& q=\&$ esrc $=$ s\& source=web\& $\mathrm{cd}=1 \& \mathrm{cad}=\mathrm{rja} \& u a-$ $\mathrm{ct}=8 \& \mathrm{ved}=0 \mathrm{CCAQFjAA} \&$ url $=\mathrm{http} \% 3 \mathrm{~A} \% 2 \mathrm{~F} \% 2$ Fkreativnost.pedagogija. net $\% 2$ Fmod $\% 2$ Fresource $\% 2$ Fview.php $\% 3$ Fid $\% 3$ D $4 \&$ ei $=$ oShaVZWBComuswHjuYHYCQ\&usg=AFQjCNGogTTtWqDH0fNcaxcOkK7LxWu1w\&bvm=bv.93564037,d.bGg (posećeno 23. 1. 2019.)

Cornell, D. \& I. Grossberg (1987): Family environment and personality adjustment in giftedprogram children, Gifted Child Quarterly, 2, 59-64.

Đorđević, B. (2008): Kreativnost i imaginacija dece i mladih. Pedagoška stvarnost.54(1-2), 5-13.

Đorđević, B i S. Maksić (2005): Podsticanje talenata i kreativnosti mladih- izazov savremenom svetu. Zbornik Instituta za pedagoška istraživanja, 38(1), 125-147.

Đorđević, J. (2008): Porodica kao faktor podsticanja darovitosti. Zbornik visoke škole strukovnih studija za obrazovanje vaspitača Vršac. br. 14, 25-35.

Ivanović, S. (2008): Porodični uslovi, slobodno vreme i kreativnost mladih. Zbornik radova visoke škole strukovnih studija za obrazovanje vaspitača Vršac. br. 14, 223-230.

Kamenov, E. (2006): Obrazovanje predškolske dece. Zavod za udžbenike i nastavna sredstva, Beograd.

Krulj, R. i Z. Arsić (2008): Osnovne pretpostavke i uslovi za razvoj darovitosti i kreativnosti u porodici. Zbornik radova visoke škole strukovnih studija za obrazovanje vaspitača, Vršac, br.14, 345-353.

Lee, B. (2013). Suggestions for language learners: Creativity development in EFLclassrooms. Primary English Education, 19(3), 87-109.

Maksić, S. (1998): Darovito dete u školi. Beograd: Institut za pedagoška istraživanja.

Maksić, S. (2006): Podsticanje kreativnosti u školi. Beograd: Institut za pedagoška istraživanja.

Maleš, D. (1993): Škola- roditelji- djeca. Obnovljeni život, 48(6), 587-593.

Matejević, M. (2007): Vrednosne orijentacije i vaspitni stil roditelja. Niš: Filozofski fakultet.

Muminović, H. (2009): Motivacija u nastavi i kreativni rad studenata i učenika. Sarajevo: DES.

Pavlović V. i S. Maksić (2009): Odnos srpske društvene elite prema dečjoj mašti i kreativnosti. Zbornik radova visoke škole strukovnih studija za obrazovanje vaspitača Vršac, br. 15, 425-439.

Popescu, T. (2013). Pre-service EFL teacher trainees' perceptions on developing pupils'creativity. Procedia-Social and Behavioral Sciences, 76, 700-705. 
Stojanović, A. (2008): Aspiracije roditelja kao faktor podsticanja darovitih učenika. Zbornik radova visoke škole strukovnih studija za obrazovanje vaspitača Vršac, br. $14,562-569$.

Somolanji I. i L. Bognar (2008): Kreativnost u osnovno školskim uvjetima. Život $i$ škola, 56(19), 87-94.

Supek, R., Sorokin, B, Nola, D. i M. (1987): Dijete i kreativnost.Zagreb: Globus.

Tsai, D-M. (2000): Parenting strategies to facilitate excellence; in K. Maitra (ed.): Towardsexcellence, developing and nurturing giftedness and talent (172-185). New Delhi: MosaicBooks. 